\title{
PEMBERDAYAAN TANAMAN Moringa Oleifera Lamk. (KELOR) PADA MASYARAKAT DUSUN TALANGSARI DESA RINGINKEMBAR KECAMATAN SUMBERMANJING WETAN KABUPATEN MALANG
}

\author{
Rif'atul Mahmudah ${ }^{1}$, Eny Yulianti ${ }^{1}$, Ahmad Hanapi $^{1}$ \\ ${ }^{1}$ Jurusan Kimia, UIN Maulana Malik Ibrahim Malang \\ rifatul_83@yahoo.com,eny.uinmlg@gmail.com,chanafi_achmad@yahoo.com
}

\section{Info Artikel \\ Riwayat Artikel: \\ Diterima: September 2017 \\ Direvisi: Agustus 2019 \\ Diterbitkan: September 2019}

\section{Keywords:}

Kelor

Nutrition

Herbal medicine

Liquid fertilizer

Natural fertilizer

\begin{abstract}
Kelor is a nutrient-rich plant that can be used for food, medicine, fertilizer as well as customary rituals and is easy to cultivate, especially in tropical climates. The geographical condition is quite fertile and the economic community of Talangsari Village Ringin twin Subdistrict Sumbermanjing Wetan Malang Regency which generally middle down with the majority work as farmers make the welfare of the community Talangsari Hamlet relatively less due to low education, and health. Community empowerment is done by counseling, socialization, training to the community about the cultivation and nutrition of moringa plants to improve nutrition, as herbal medicine and organic liquid fertilizer and then conducted monitoring and evaluation. The result of the research shows that the increasing of interest for the cultivation of moringa kelor with the growing number of kelor planted, the effectiveness of kelor leaf extract as a natural fertilizer, in addition leaf kelor proven to alleviate various diseases such as uric acid and diabetes.
\end{abstract}

Copyright $(\mathrm{C} 2019 \mathrm{JRCE}$. All rights reserved.

\footnotetext{
Korespondensi:

Penulis,

UIN Maulana Malik Ibrahim Malang,

J1. Gajayana No. 50 Malang, Jawa Timur, Indonesia 65144

rifatul_83@yahoo.com
}

\section{PENDAHULUAN}

Tanaman kelor (Moringa oleifera Lamk.) merupakan tanaman paling kaya nutrisi yang banyak dimanfaatkan di negara Asia dan Afrika sebagai bahan pangan dan pengobatan karena lebih banyak mengandung protein, vitamin, mineral, anti-oksidan kuat tertinggi, dan asam amino esensial lengkap dibanding tanaman lainnya (Amzu, 2014, Moyo, 2011, Mahmood, 2010). Menurut Kepmen dalam negeri RI no. 140-9756 tahun 2016 Indonesia memiliki 74.910 desa, dimana masyarakat desa tersebut membutuhkan penguatan kapasitas sumberdaya manusia untuk meningkatkan kesejahteraan mereka. Salah satu upaya meningkatkan kesejahteraan mereka adalah diantaranya adalah pemberdayaan konservasi tanaman kelor, melalui gerakan penanaman dan pemanfaatan tanaman kelor (Moringa oleifera Lamk.) dalam rangka mendukung gerakan nasional sadar gizi, mengatasi malnutrisi, peningkatan hasil produksi pertanian di Indonesia.

Kelor merupakan tumbuhan serbaguna karena semua bagian tumbuhan dari tersebut dapat dimanfaatkan mulai dari daun, kulit batang, bunga, buah (polong), sampai akarnya (Sauveur, 2010; Krisnadi, 
2012). Tanaman kelor di Pulau Jawa sering dimanfaatkan sebagai tanaman pagar karena berkhasiat untuk obat-obatan seperti obat sariawan, diabetes, pegal linu, sakit kepala, gatal-gatal dll, dimanfaatkan juga sebagai pakan ternak seperti sapi dan kambing dan ritual adat seperti memandikan jenazah (Winarno, 2006; Bahriyah et al. 2015). Ekstrak daun kelor (EDK) dapat digunakan sebagai pupuk organik untuk mempercepat pertumbuhan tanaman secara alami karena kaya kandungan zeatin, sitokinin, askorbat, fenolik, dan mineral seperti $\mathrm{Ca}, \mathrm{K}$, dan Fe yang memicu pertumbuhan tanaman dan dapat diaplikasikan pada semua jenis tanaman. Pemberian pupuk cair dengan cara disemprotkan menunjukkan percepatan pertumbuhan tanaman muda, tanaman yang lebih kokoh, lebih tahan terhadap hama dan penyakit, memperpanjang masa hidup, meningkatkan berat akar, batang dan daun, menghasilkan buah yang lebih besar, lebih banyak buah, dan peningkatan hasil panen $20 \%$ - 35\% (Foidl et al. 2001).

Dusun Talangsari terletak di Desa Ringin Kembar Kecamatan Sumber Manjing Wetan, sebuah kecamatan di Kabupaten Malang dengan topografi wilayah berupa pegunungan. Kecamatan ini berbatasan langsung dengan samudera Indonesia (selatan), Kec. Gedangan (barat), Kec. Turen (utara), Kec. Dampit (timur). Dusun Talangsari Desa Ringin kembar Kecamatan Sumbermanjing Wetan Kabupaten Malang terletak di dataran tinggi yang cukup subur untuk dimanfaatkan sebagai lahan pertanian dan perkebunan seperti tebu, kopi, singkong, pisang, tomat, cabe dll. Potensi tanaman kelor di dusun Talangsari Desa Ringin kembar Kecamatan Sumbermanjing Wetan Kabupaten Malang tersebut masih sedikit dilakukan. Keberadaan tanaman kelor juga masih minim, karena minat yang kurang untuk menanam disebabkan kurangnya pengetahuan tentang manfaat kelor. Selama ini masyarakat memanfaatkan kelor sebagai makanan ternak dan ritual adat tanpa tahu manfaat atau nutrisi yang ada pada daun kelor. Tanaman kelor mudah untuk dibudidayakan karena bisa tumbuh baik di wilayah iklim tropis. Umumnya masyarakat pedesaan sudah cukup berpengalaman dalam menanam kelor, biasanya untuk tanaman pembatas/pagar di sekitar rumah atau di ladang. Hal tersebut yang menjadi dasar peneliti bahwa masyarakat membutuhkan informasi tentang nutrisi yang ada pada tanaman kelor dan pengaruh mengkonsumsi kelor bagi kesehatan, kelor sebagai tanaman herbal selain itu juga pemanfaatan kelor untuk pupuk alami sehingga meningkatkan produksi atau hasil pertanian tanpa harus memakai pupuk kimia.

Pemberdayaan masyarakat dengan tema "Budidaya Kelor (Moringa oleifera Lamk) untuk Indonesia Makmur" perlu dilakukan karena mempertimbangkan bahwa mayoritas masyarakat dusun Talangsari Desa Ringin kembar Kecamatan Sumbermanjing Wetan Kabupaten Malang bekerja sebagai petani/buruh dengan pemasukan/upah yang tidak seberapa. Penggunaan pupuk kimia untuk pertanian/perkebunan selain harganya cukup mahal yang tentunya akan membebani masyarakat ekonomi lemah juga akan membuat tanah atau hama menjadi resisten. Kondisi ekonomi masyarakat yang umumnya memprihatinkan (menengah kebawah) menjadikan kesejahteraan masyarakat Dusun Talangsari relatif kurang dikarenakan rendahnya pendidikan, kesehatan dan juga keadaan rumah yang kurang begitu layak.

\section{METODE PENELITIAN}

Alat dan bahan yang digunakan dalam penelitian ini adalah kamera, alat tulis, LCD proyektor, daun kelor, peralatan memasak untuk membuat aneka makanan berbahan daun kelor, alat penumbuk untuk pembuatan ekstrak cair kelor, bibit kelor.

Metode penelitian ini menggunakan pendekatan observasi dengan teknik wawancara terhadap warga dusun talangsari dan pengamatan di lapangan. Penyusunan program pengabdian masyarakat dilakukan oleh tim peneliti dari UIN Maulana Malik Ibrahim Malang bersama Kepala Dusun Talangsari, pengurus Posdaya dan sebagian warga melalui musyawarah bertempat di Masjid Al Hikmah Dusun Talangsari Desa Ringin Kembar Kecamatan Sumber Manjing Wetan. Berdasarkan hasil musyawarah yang dilakukan pada hari Sabtu tanggal 24 September 2016 disepakati beberapa program Posdaya di Dusun Talangsari, antara lain: Penyuluhan dan sosialisasi kepada masyarakat tentang nutrisi tanaman kelor dilakukan dengan metode ceramah/presentasi menggunakan LCD, video, dan membagikan booklet sehingga masyarakat memiliki gambaran tentang manfaat dari menanam tanaman kelor tersebut seperti sebagai obat herbal dan pupuk cair organik. Menyebarluaskan benih dan bibit tanaman kelor kepada masyarakat dengan demonstrasi bagaimana cara budidayanya, mengadakan pelatihan terkait cara pembuatan pupuk alami dari daun kelor dan bersamasama dengan masyarakat mengaplikasikan pupuk pada tanaman untuk mengetahui perbedaan pertumbuhan antara tanaman yang di beri pupuk alami dari kelor dan yang tanpa pupuk. Harapannya pupuk tersebut bisa menggantikan pupuk buatan yang selama ini dipakai dan sebagai penyebab biaya terbesar dalam produktivitas pertanian. Mengadakan perlombaan memasak berbahan baku kelor sehingga memotivasi masyarakat untuk memanfaatkan kelor dengan berbagai jenis variasi masakan. Memantau dan mengevaluasi implementasi kegiatan ini, terus memberikan akses sharing dan konseling antara subjek dampingan dalam hal ini masyarakat dan pelaksana kegiatan pemberdayaan ini (dosen UIN Malang). Komunikasi dapat melalui 
pertemuan informal misalnya telepon, dan kami akan terjun langsung ke lapangan dalam memantau kegiatan pemberdayaan ini sehingga menjadi kegiatan pemberdayaan yang berkelanjutan.

\section{HASIL DAN PEMBAHASAN}

Pengabdian masyarakat ini bertujuan agar masyarakat desa dusun Talangsari menggalakkan gerakan menanam kelor sehingga menjadikan dusun tersebut sebagai Kampung Kelor, dimana masyarakat mampu secara mandiri membudidayakan, memanfaatkan tanaman kelor untuk kesehatan, dan penambah nutrisi, bahkan menyebar luaskan informasi tentang pemanfaatan kelor sebagai tanaman herbal pada masyarakat dusun lainnya. Tujuan lainnya yaitu masyarakat mampu secara bertahap mengurangi ketergantungan petani memakai pupuk kimia dengan menggantinya pada pupuk alami dari daun kelor.

Sosialisasi tentang berbagai nutrisi yang ada pada kelor dan membandingkannya dengan nutrisi yang ada pada buah dan sayuran yang lain menunjukkan bahwa kelor meskipun hanya sayuran tetapi punya kandungan nutrisi yang sangat besar daripada buah buahan lainnya. Pemanfaatan daun kelor sebagai tanaman penambah nutrisi dan pengobatan dengan mengolah aneka makanan berbahan baku kelor seperti puding kelor, bolu kelor dan lumpur kelor yang dibuat oleh tim peneliti dan dibagikan kepada masyarakat. Selain itu juga mengadakan lomba membuat aneka makanan olahan dari kelor, yang diikuti oleh ibu-ibu dusun Talangsari dalam bentuk kelompok (gambar 1). Harapannya masyarakat lebih bersemangat mengkonsumsi kelor, karena diolah menjadi aneka makanan tidak harus dalam bentuk jamu atau kapsul.

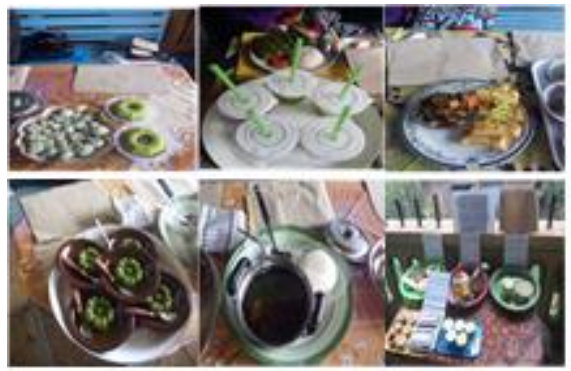

Gambar 1. Makanan berbahan baku kelor yang dibuat ibu -ibu warga Dusun Talangsari

Selain itu juga sosialisasi tentang manfaat kelor sebagai herbal dalam kegiatan tersebut sekaligus mendetilkan beberapa penyakit yang bisa sembuh dengan mengkonsumsi tanaman kelor. Hasil wawancara terhadap masyarakat dengan usia diatas 40 tahun beberapa menderita gejala stroke seperti sakit kepala, darah tinggi, diabetes, asam urat, dan pegal linu. Tim menyarankan warga menderita keluhan tersebut untuk mengkonsumsi tanaman kelor, terutama daunnya, dengan kreatif mengolahnya menjadi aneka makanan. Program ini tim akan mengamati hasilnya saat kunjungan berikutnya. Hasil wawancara menunjukan bahwa konsumsi kelor setiap hari mengurangi berbagai keluhan yang dialami warga seperti berkurangnya tingkat kadar gula dan berkurangnya rasa nyeri karena asam urat.

Sosialisasi pemanfaatan kelor sebagai pupuk organik cair diikuti oleh bapak-bapak dan pemudapemuda dari dusun Talangsari. Dalam materi sosialisasi tersebut disampaikan tentang berbagai penelitian dari sumber jurnal terpercaya yang isinya tentang pemanfaatan kelor sebagai pupuk cair organik. Juga tentang aplikasi pupuk cair kelor tersebut terhadap tanaman, sampai diperoleh kesimpulan bahwa pupuk cair kelor sangat bagus untuk pertumbuhan tanaman, seperti tebu, bawang merah, maupun kelor itu sendiri. Selain itu disampaikan juga tentang cara pembuatan pupuk cair kelor, ditambah dengan pemutaran video yang menayangkan tentang praktek pembuatan pupuk cair kelor. Pupuk cair kelor segar hasil praktek tersebut kemudian didiamkan/diperam dalam botol selama kurang lebih satu minggu. Setelah diperam satu minggu, pupuk tersebut digunakan kembali untuk menyemprot tanaman bawang prei. Satu pot bawang prei di semprot dengan pupuk cair kelor dan yang satu lagi tanpa disemprot (sebagai kontrol) Hasil menunjukkan bahwa tanaman yang diberi pupuk kelor memiliki daun yang lebih besar dan tunas yang lebih banyak dibanding dengan tanaman kontrol. Penelitian ini diamati dan disaksikan sendiri oleh peserta pelatihan sehingga membuat peserta pelatihan menjadi lebih bersemangat dan antusias untuk mulai menggunakan pupuk cair kelor.

Monitoring dan evaluasi dilakukan dengan membentuk kader kelor dusun Talangsari yang dapat membudidayakan kelor secara mandiri dan memanfaatkan kelor secara maksimal yang terdiri dari bapakbapak/pemuda-pemuda dan ibu-ibu. Dengan harapan, bapak-bapak bertugas sebagai pembudidaya tanaman kelor (mencari bibit, memperbanyak dan menanamnya di pekarangan rumah dan sepanjang jalan dusun) dan pembuat pupuk cair kelor, sedangkan ibu-ibu bertugas mengolah kelor menjadi makanan sehat untuk 
keluarganya. Selain itu terbentuk kader kelor dusun Talangsari juga diharapkan menularkan program "Kelorisasi" tersebut ke dusun lain sekitar Talangsari atau daerah lain, dimana kader kelor dusun Talangsari bertindak sebagai narasumber. Tim dari UIN malang juga secara rutin berkomunikasi dengan warga untuk mengevaluasi dan memonitor apakah program tetap berjalan dan membantu kesulitan-kesulitan yang dialami selama pelaksanaan program.

Perubahan yang terjadi setelah kegiatan pengabdian masyarakat yaitu: warga menjadi bersemangat untuk menanam kelor dilihat dari banyaknya tanaman kelor di sepanjang jalan dusun dan dipekarangan rumah mereka, warga mulai membuat pupuk cair kelor dan mengaplikasikannya untuk tanaman mereka. Masyarakat mampu secara mandiri menyebar luaskan informasi tentang manfaat kelor dan menjadi narasumber program kelorisasi di beberapa dusun sekitar.

\section{KESIMPULAN}

Berdasarkan penelitian yang telah dilakukan bersama warga, ekstrak daun kelor dapat digunakan sebagai tanaman herbal meringankan berbagai penyakit. Selain itu daun kelor bisa dimanfaatkan untuk pupuk tanaman dan diharapkan dapat mengurangi penggunaan pupuk kimia oleh warga sehingga mengurangi pengeluaran warga untuk membeli pupuk kimia. Perlu adanya pendampingan yang lebih lama dan berkesinambungan dari tim Posdaya UIN Maulana Malik Ibrahim Malang sampai warga dapat mengeksplorasi manfaat kelor secara maksimal dan dapat membuat berbagai macam produk kelor yang bernilai ekonomis.

\section{UCAPAN TERIMAKASIH}

Peneliti menyampaikan ucapan terima kasih yang sebesar besarnya kepada Lembaga Penelitian dan Pengabdian Masyarakat (LP2M) UIN Maulana Malik Ibrahim Malang atas dana program Participatory Action Research (PAR) yang diberikan untuk pengabdian masyarakat ini.

\section{DAFTAR PUSTAKA}

Amzu, 2014. Kampung Konservasi Kelor: Upaya Mendukung Gerakan Nasional Sadar Gizi Dan Mengatasi Malnutrisi Di Indonesia. Risalah Kebijakan Pertanian dan Lingkungan. Vol. 1 No. 2: 86

Bahriyah, Izzatul, Hayati, Ari, Zayadi, Hasan. 2015. Studi Etnobotani Tanaman Kelor (Moringa oleifera ) di Desa Somber Kecamatan Tambelangan Kabupaten Sampang Madura. e-Jurnal Ilmiah BIOSAINTROPIS (BIOSCIENCETROPIC) Volume :1 (1), 2015, 61 - 67

Foidl, N, Makkar, H, Becker, K. 2001. In The Miracle Tree: The Multiple Uses of Moringa (Ed, J, F.) Wageningen, Netherlands. pp. 45-76

Krisnadi AD. 2012. Kelor Super Nutrisi. Blora (ID): Pusat Informasi dan Pengembangan Tanaman Kelor Indonesia. Lembaga Swadaya Masyarakat Media Peduli Lingkungan (LSMMEPELING). Kunduran. Yogyakarta.

Mahmood, T. H. 2010. Moringa oleifera: a natural gift-A review. J. Pharm. Sci. \& Res. Vol.2 (11), 2010,775-781.

Moyo, B. 2011. Nutritional characterization of Moringa (Moringa oleifera Lam.) leaves. African Journal of Biotechnology Vol. 10(60), pp. 12925-12933

Sauveur, A.S., Broin, M. 2010. Growing and Processing Moringa Leaves. Ghana: Moringa Association of Ghana Winarno, F.G. 2006. Kimia Pangan dan Gizi. Jakarta: Gramedia Pustaka Utama 